sulphate), but these devices were not wound with copper wire. This report must be viewed in the context that limb reduction deformities occur in about 1 in 5000 of live births.

We have seen several cases of spontaneous abortion occuring after conception in the presence of an IUD. One such case was an anencephalic fetus of 11 weeks' gestation. As anencephaly and spina bifida are present in about $5 \%$ of the spontaneously aborted fetuses we see, 20 the importance of our observation must be tested in larger series of pregnancies occurring with IUDs in situ. Our finding of progressive calcification suggests, however, that any teratogenic effects attributable to copper may be limited to the precalcification period. Nevertheless, despite the reassuring experimental work on rodents and human tissue cultures, ${ }^{21}$ it is unrealistic on the available evidence to dismiss the possibility of a teratogenic effect from a retained intrauterine device. More information is urgently needed on the outcome of pregnancies complicated by the presence of IUDs.

\section{FUTURE STUDIES}

New types of IUD, such as those that depend on the sustained release of progesterone, are being developed. In view of the calcium deposition that may occur the efficiency of such IUDs should be carefully evaluated. A study of drug or copper levels in the cervical mucus while the device is still in situ would be a simple and accurate way of indicating whether the substance was still being released. It might also detect women in whom the deposition of calcium is particularly rapid. Possibly conception in the presence of an IUD that releases metal or a drug is more common in women who suffer rapid calcification.
Grant for their help and discussions during the progress of this work, and the medical and nursing staff of the Lothian Health Board Family Planning Services for their help and for collecting the devices. We are indebted to Mr A R Ross and Miss C Gray for their expert technical help.

\section{References}

1 Zipper, J A, et al, American fournal of Obstetrics and Gynaecology, 1969, $105,2274$.

2 Zipper, J A, et al, American fournal of Obstetrics and Gynaecology, 1971, $109,771$.

${ }^{3}$ Middleton, J C, and Kennedy, M, Contraception, 1975, 11, 209.

4 Teitze, C, and Lewit, S, Studies in Family Planning, 1970, 55, 1.

${ }^{5}$ Hagenfeldt, K, Contraception, 1972, 6, 37.

${ }^{6}$ Daunter, B, and Elstein, M, Journal of Obstetrics and Gynaecology of the British Commonwealth, 1973, 80, 644.

7 Tatum, H J, Clinical Obstetrics and Gynecology, 1974, 17, 93.

${ }^{8}$ Gupta, P K, Malkini, P K, and Bhasin, K, Contraception, 1971, 4, 375.

- Gibor, Y, Population Report. Washington, George Washington University Medical Centre, 1973.

${ }^{10}$ Zielske, S, et al, Contraception, 1974, 10, 651.

11 Newton, J, British Medical fournal, 1977, 1, 197.

12 Jain, A K, Contraception, 1974, 11, 243.

13 Snowden, R, British Medical fournal, 1976, 1, 770.

${ }^{14}$ Rosado, A, et al, American fournal of Obstetrics and Gynecology, 1972, 114, 88.

15 Hernandez, O, et al, Contraception, 1975, 11, 451.

16 Whitten, W K, Advances in Biosciences, 1971, 6, 129.

17 Whittington, D G, in Society for Study of Reproduction, 5th Annual Meeting. Cambridge, Reproduction Research Information Ltd, 1972.

18 Alderman, B, British Medical fournal, 1975, 1, 770.

19 Barrie, H, British Medical fournal, 1976, 1, 488.

${ }^{20}$ Bell, J, and Gosden, C, in preparation.

${ }^{21}$ Jones, R W, Gregson, N M, and Elstein, M, British Medical fournal, 1973, 2, 520 .

(Accepted 2 December 1976)

\title{
Liver-cell-membrane autoantibody specific for inflammatory liver diseases
}

\author{
U TAGE-JENSEN, W ARNOLD, O DIETRICHSON, F HARDT, U HOPF, \\ K H MEYER ZUM BÜSCHENFELDE, J O NIELSEN
}

British Medical fournal, 1977, 1, 206-208

\section{Summary}

With an immunofluorescence technique using rabbit hepatocytes isolated by a non-enzymatic method an autoantibody directed against liver-cell-membrane was identified. Sera from 361 patients with various liver diseases and 274 patients with primary non-hepatic diseases-many associated with non-organ-specific auto-

\footnotetext{
Second Department of Internal Medicine, Kommunehospitalet, Department $M$, Rigshospitalet and Division of Hepatology, Hvidovre Hospital, Copenhagen, Denmark

U TAGE-JENSEN, $M D$, registrar

F HARDT, $M D$, senior registrar

J O NIELSEN, $M D$, senior registrar

O DIETRICHSON, MD, senior registrar

Second Department of Internal Medicine, University of Mainz, Mainz, West Germany

W ARNOLD, MD, senior registrar

U HOPF, MD, senior registrar

K H MEYER ZUM BỨSCHENFELDE, MD, professor
}

antibodies-were examined. The antibody (LMA) was found in 27 out of 72 patients with hepatitis-B-surface antigen (HBsAg)-negative chronic active hepatitis and in 17 out of 28 patients with $\mathrm{HBsAg-negative} \mathrm{non-}$ alcoholic cirrhosis. Only two patients had LMA and HBsAg, and both had chronic active hepatitis. One patient with extrahepatic disease was found to have LMA, and this patient had biochemical evidence of liver disease.

Hence there is a close correlation between the presence of LMA and HBsAg-negative chronic inflammatory liver disease and its detection may help in diagnosis.

\section{Introduction}

There are several different causes of chronic liver disease. Serologically most patients with chronic active liver disease (CALD) may be separated into two groups: one with circulating hepatitis B surface antigen (HBsAg) and the other with nonorgan-specific autoantibodies. ${ }^{1-3}$

An autoimmune mechanism may be concerned in the pathogenesis of the liver damage in patients with circulating autoantibodies. ${ }^{4}$ In these patients, however, the meaning and importance of autoimmunity as shown by the presence of non-organ-specific 
autoantibodies-smooth-muscle antibody (SMA), antinuclear antibody (ANA), and antimitochondrial antibody (AMA)-are uncertain.

The concept of an autoimmune pathogenesis was supported by Meyer zum Büschenfelde and Miescher, ${ }^{5}$ who purified and characterised a liver-specific protein that was later shown to induce chronic liver disease in rabbits. ${ }^{6}$ The finding of an autoantibody directed against the hepatocyte membrane in HBsAg-negative chronic active hepatitis ${ }^{7}$ further supports this theory.

We have tried to elucidate the disease specificity of this livercell-membrane antibody (LMA) by examining patients with acute and chronic liver disease as well as patients with extrahepatic disease, which is often associated with the presence of autoantibodies.

\section{Patients and methods}

We studied 635 patients from Mainz and Copenhagen; 361 had various liver diseases and 274 primary non-hepatic diseases. The diagnoses are listed below.

Acute viral type $B$ hepatitis - Twenty-eight patients had acute viral hepatitis proved by biopsy and circulating HBsAg.

Acute non-B hepatitis - Thirty-one patients had acute viral hepatitis proved by biopsy but no circulating HBsAg or antibody (HBsAb).

Resolved type $B$ hepatitis-Seventy-seven patients had recovered from type $B$ hepatitis.

Chronic active hepatitis-A total of 114 patients had histological and biochemical evidence of chronic active hepatitis. Circulating HBsAg was present in 42 .

Chronic persistent hepatitis-Thirty-four patients had histological changes and a clinical picture compatible with chronic persistent hepatitis. Sixteen were HBsAg-positive.

Cirrhosis (non-alcoholic) - Forty patients had histological evidence of cirrhosis. Twelve were HBsAg-positive.

Primary biliary cirrhosis-Nine patients had clinical and histological evidence of primary biliary cirrhosis. All had circulating AMA and were HBsAg-negative.

Miscellaneous liver diseases-Eight patients had periportal fibrosis and non-specific inflammation.

Metabolic liver diseases - Twenty patients had alcoholic cirrhosis and steatosis of the liver.

Primary non-hepatic diseases-Of the 274 patients with primary non-hepatic diseases, five had haemochromatosis, 30 Crohn's disease, 30 ulcerative colitis, 33 systemic lupus erythematosus, 58 rheumatoid arthritis, 27 active tuberculosis, 14 active glomerulonephritis, nine polymyalgia rheumatica, 50 mononucleosis, and 18 sarcoidosis.

\section{CONTROLS}

Forty unselected healthy blood donors served as controls.

\section{SEROLOGICAL METHODS}

HBsAg was detected by immunoelectro-osmophoresis and radioimmunoassay (Ausria-II-125).

LMA was detected by an indirect immunofluorescence technique with the use of rabbit hepatocytes isolated by a non-enzymatic method. ${ }^{7}$ Rabbit hepatocytes $(50 \mu \mathrm{l})$ were incubated in $150 \mu \mathrm{l}$ of each patient's serum (diluted $1 / 4$ ) for 30 minutes at $37^{\circ} \mathrm{C}$. The cell suspension was then washed three times in Eagle's medium with bovine serum albumin. The sediment was incubated in $150 \mu \mathrm{l}$ of fluoresceinisothiocyanate-labelled antihuman IgG (Dakopatt) and prepared as described above. Control samples included normal human serum, native rabbit hepatocytes with fluorescein-isothiocyanate-labelled antihuman IgG, and native rabbit hepatocytes with labelled antirabbit IgG. The presence of LMA was shown by a linear fluorescence distinct from the granular pattern of $\mathrm{Fc}$ receptors and binding of immune complexes. ${ }^{8}$ Non-specific binding of IgG to the hepatocyte membrane was excluded by use of the control samples and by the negative findings in HBsAg-positive patients with chronic active hepatitis and other groups of patients with high levels of IgG. Titration was performed on a few samples and gave values of between $1 / 16$ and $1 / 252$. All sera were tested under code. An indirect immunofluorescence technique ${ }^{3} 7$ was used to detect ANA and SMA.

\section{Results}

LMA was found in 55 of the 635 patients (table I), predominantly (46 cases) in those with HBsAg-negative chronic liver disease. LMA was also found in five of the 31 patients with acute non-B hepatitis. In contrast, LMA was detected in only two out of 98 patients with HBsAg-positive acute and chronic liver diseases. Of the remaining 311 patients with various diseases, only one, a patient with ulcerative colitis, was found to have LMA. This patient refused liver biopsy but had biochemical evidence of liver disease. LMA was not found in any of the controls.

In contrast to the finding of LMA in five of the 31 patients with acute non- $B$ hepatitis, none of the 28 patients with acute type $B$ hepatitis had LMA (table I). Follow-up studies including liver biopsy were performed on 22 of the 28 patients with acute type $B$ hepatitis and on 21 of the 31 with non-B hepatitis. Of the patients with acute type B hepatitis, 17 had complete resolution of their disease and five progressed to CALD; of the patients with non-B hepatitis, 17 (two with LMA) had complete resolution of their disease and four (three with LMA) progressed to CALD. These numbers were too small to be evaluated statistically.

TABLE I-Presence of LMA in different groups of patients

\begin{tabular}{|c|c|c|c|c|c|c|}
\hline \multirow{2}{*}{\multicolumn{4}{|c|}{ Diagnosis }} & \multirow{2}{*}{$\begin{array}{c}\text { No of } \\
\text { patients }\end{array}$} & \multicolumn{2}{|c|}{ Patients with LMA } \\
\hline & & & & & No & $\%$ \\
\hline \multicolumn{4}{|l|}{ Acute viral hepatitis: } & \multirow{4}{*}{$\begin{array}{l}31 \\
28 \\
77\end{array}$} & \multirow{3}{*}{5} & \multirow{3}{*}{16} \\
\hline $\begin{array}{l}\text { HBsAg-negative } \\
\text { HBsAg-positive }\end{array}$ & . & . & . & & & \\
\hline $\begin{array}{l}\text { HBsAg-positive } \\
\text { Recovered from type } \ddot{B}\end{array}$ & & $\cdots$ & .. & & & \\
\hline \multicolumn{2}{|c|}{$\begin{array}{l}\text { Recovered from type B hepatitis } \\
\text { Chronic active hepatitis: }\end{array}$} & $\cdots$ & .. & & 1 & 1 \\
\hline $\begin{array}{c}\text { Chronic active hepatitis } \\
\text { HBsAg-negative .. }\end{array}$ & & & & 72 & \multirow{2}{*}{$\begin{array}{r}27 \\
2\end{array}$} & \multirow{2}{*}{$\begin{array}{r}38 \\
5\end{array}$} \\
\hline HBsAg-positive $\ldots$ & $\because$. & $\because$ & $\because$ & 42 & & \\
\hline \multicolumn{4}{|c|}{ Chronic persistent hepatitis: } & & \multirow{3}{*}{2} & \multirow{3}{*}{11} \\
\hline HBsAg-negative .. & .. & . & . & 18 & & \\
\hline \multirow{2}{*}{\multicolumn{4}{|c|}{ Cirrhosis: }} & 16 & & \\
\hline & .. & 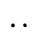 & .. & 28 & \multirow{2}{*}{17} & \multirow{2}{*}{61} \\
\hline HBsAg-positive $\quad$. & .. & .. & .. & 12 & & \\
\hline Primary biliary cirrhosis & .. & .. & .. & 9 & \multirow{14}{*}{1} & \multirow{14}{*}{3} \\
\hline Metabolic liver diseases & .. & $\cdots$ & .. & 20 & & \\
\hline Miscellaneous liver dise & ... & . & . & 8 & & \\
\hline Haemochromatosis .. & . & . & .. & 5 & & \\
\hline Crohn's disease & . & . & .. & 30 & & \\
\hline Ulcerative colitis $\ldots$ & & . & .. & 30 & & \\
\hline \multicolumn{2}{|c|}{ Systemic lupus erythematosus } & . & .. & 33 & & \\
\hline Rheumatoid arthritis .. & . & .. & .. & 58 & & \\
\hline Active tuberculosis .. & .. & .. & .. & 27 & & \\
\hline Glomerulonephritis .. & . & . & . & 14 & & \\
\hline Polymyalgia rheumatica & & .. & .. & 9 & & \\
\hline Mononucleosis $\quad$.. & . & $\cdots$ & .. & 50 & & \\
\hline 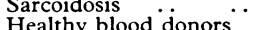 & $\cdots$ & $\cdots$ & . & 18 & & \\
\hline Healthy blood donors & & & & & & \\
\hline
\end{tabular}

Of all 188 patients with CALD, 48 had LMA and 140 did not (table II). The LMA-positive patients were mainly elderly women with a high prevalence of non-organ-specific autoantibodies, whereas the patients without LMA had a more even sex distribution, a lower mean age, and a much lower prevalence of autoantibodies.

Out of 461 patients with HBsAg-negative CALD and LMA, 36 were found to have either SMA or ANA or both, leaving 101 with neither of these two autoantibodies. Of the LMA-negative patients with CALD, about one-third of the HBsAg-negative cases had SMA or ANA or both compared with none of the HBsAg-positive cases. Many patients with extrahepatic diseases were found to have autoantibodies, mostly ANA, but none of these patients was positive for LMA.

Table II shows that acute onset of CALD and the presence of HBsAg occurred predominantly in the patients without LMA. Nineteen patients with LMA and 23 without LMA were having immunosuppressive treatment.

TABLE II-Clinical and serological variables in 188 patients with CALD with and without $L M A$

\begin{tabular}{|c|c|c|c|}
\hline & & $\begin{array}{c}\text { Patients } \\
\text { with LMA } \\
(\mathrm{n}=48)\end{array}$ & $\begin{array}{l}\text { Patients } \\
\text { without LMA } \\
(n=140)\end{array}$ \\
\hline $\begin{array}{l}\text { Sex }(F / M) \\
\text { Mean age in years (range) } \\
\text { Type of onset of disease: }\end{array}$ & $\begin{array}{ll} & .\end{array}$ & $\begin{array}{c}40 / 8 \\
55(21-86)\end{array}$ & $\begin{array}{c}64 / 76 \\
42(17-88)\end{array}$ \\
\hline $\begin{array}{llll}\text { Acute } & \cdots & . & \ldots\end{array}$ & .. & 29 & 99 \\
\hline Insidious $\ldots$ & . & 19 & \\
\hline HBsAg present $\quad \ldots \quad \ldots$ & . & 2 & 68 \\
\hline Antinuclear factor present ... & .. & 34 & 32 \\
\hline Smooth-muscle antibody present & $\because$. & 22 & 27 \\
\hline Immunosuppressive treatment & 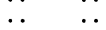 & 19 & 23 \\
\hline
\end{tabular}




\section{Discussion}

Hopf et $a l^{7}$ found LMA in sera from several patients with $\mathrm{HBsAg}$-negative chronic active hepatitis. LMA may be regarded as an autoantibody since it reacts with the membranes of normal human hepatocytes and may be absorbed with a freshly prepared human liver membrane fraction containing liver-specific protein. The relation between LMA and liver-specific protein, however, has not yet been clarified. We found LMA in over a third of the patients in this group. It is important, however, that 51 of the 55 patients with LMA had HBsAg-negative acute or chronic liver diseases, 46 of them having chronic liver disease.

In contrast to previously described non-organ-specific autoantibodies (ANA, AMA, SMA), LMA was found exclusively in patients with inflammatory liver diseases and in none of the patients with so-called autoimmune diseases such as systemic lupus erythematosus, rheumatoid arthritis, and glomerulonephritis. LMA thus seems to be disease-specific. LMA was found in 10 serum samples without any detectable ANA or SMA, which underlines that it differs from any other autoantibody known.

The uniform finding of LMA in serum samples from patients with HBsAg-negative chronic active hepatitis supports the hypothesis of an autoimmune mechanism, which accords with the previously shown high prevalence of HLA-B8 (HL-A8), ${ }^{9}$ cell-mediated immunity to the liver-specific protein, ${ }^{10}$ and the $\mathrm{K}$-cell cytotoxicity to hepatocytes ${ }^{11}$ in these patients.

From these findings one may differentiate between CALD initiated by an $\mathrm{HB}$-virus infection and $\mathrm{HBsAg}$-negative CALD, in which an autoimmune mechanism seems to be concerned in the pathogenesis. In the last group the initiating trigger mechanism may well be an infection with a virus, but probably not the HBvirus.
Although the exact pathogenic mechanisms of $\mathrm{HBsAg}$ negative, LMA-positive liver diseases remain obscure, it is of practical clinical interest that LMA is an autoantibody exclusively associated with $\mathrm{HBs} \mathrm{Ag}$-negative acute and chronic liver diseases. Like AMA, which is of diagnostic value in primary biliary cirrhosis, LMA can be used to identify a substantial population within the great heterogeneous group of patients with CALD.

This work has been supported by grants from the Danish State Medical Research Council (Nos 512-2648, 3077, and 4352); Deutsche Sonderforschungsbereich (No 107); the Medical Research Foundation for Copenhagen, Greenland, and Faeroe Islands; and the Ebba Celinders Foundation.

\section{References}

1 Wright, R, Lancet, 1970, 1, 521.

2 Vischer, T L, British Medical fournal, 1970, 2, 695.

${ }^{3}$ Dietrichson, O, et al, Acta Pathologica et Microbiologica Scandinavica, section B, 1973, 81, 519.

${ }^{4}$ Doniach, D, and Walker, J G, Lancet, 1969, 1, 813.

5 Meyer zum Büschenfelde, $\mathrm{K} \mathrm{H}$, and Miescher, $\mathrm{P}$ A, Clinical and Experimental Immunology, 1972, 10, 89.

${ }^{6}$ Meyer zum Büschenfelde, $\mathrm{K} \mathrm{H}$, Kössling, F K, and Miescher, $\mathbf{P}$ A, Clinical and Experimental Immunology, 1972, 11, 99.

${ }^{7}$ Hopf, U, Meyer zum Büschenfelde, $\mathrm{K} \mathrm{H}$, and Arnold, W, New England fournal of Medicine, 1976, 294, 578.

${ }^{8}$ Hopf, U, Meyer zum Büschenfelde, $\mathrm{K} \mathrm{H}$, and Dierich, M, fournal of Immunology, 1976, 117, 639.

${ }^{9}$ Lindberg, J, et al, British Medical fournal, 1975, 4, 77.

10 Miller, J, et al, Lancet, 1972, 2, 296.

11 Cochrane, A M G, et al, Lancet, 1976, 1, 441.

(Accepted 16 November 1976)

\section{SHORT REPORTS}

\section{Value of radiochromium investigation in autoimmune haemolytic anaemia}

Radioisotopic $\left({ }^{51} \mathrm{Cr}\right)$ labelling of red cells to measure erythrocyte survival and assess the importance of the liver and spleen in the destruction of red cells is now standard practice in haematology laboratories. There is still disagreement, however, on the reliability of surface counting in predicting the outcome of splcnectomy in individual patients with haemolytic disease, particularly those with autoimmune haemolytic anaemia. One group found that ${ }^{51} \mathrm{Cr}$ studies identified patients likely to benefit from splenectomy, ${ }^{1}$ but others have found these investigations less reliable. ${ }^{2}$ We report here the results of such measurements in 12 patients with autoimmune haemolytic anaemia.

\section{Patients, methods, and results}

All 12 patients had a direct antiglobulin titre greater than $1 / 40$ and evidence of haemolysis on the basis of normal laboratory criteria. Standard haematological methods were used. The spleen :liver ratio was assessed by body surface measurements, the ratio of organ uptake of radioactivity being measured when half the intravenously injected ${ }^{51} \mathrm{Cr}$ had left the circulation $\left(\mathrm{t}^{12^{51}} \mathrm{Cr}\right)$. A value greater than 2.5 is generally regarded as predicting a beneficial result from splenectomy. ${ }^{1}$ The splenic sequestration index (SSI), which is the percentage increment in spleen:heart radioactivity between zero time and $t_{2}^{151} \mathrm{Cr}$, was calculated as follows: $S S I=R_{50}-R_{0} \times 100$, where $R_{50}=$ spleen:heart ratio at $t_{2}^{\frac{1}{2}} \mathrm{Cr}$ and $R_{0}=$ spleen :heart ratio at zero time. A value greater than 100 is believed to indicate moderate to severe red cell sequestration in the spleen. ${ }^{4}$ Six patients were able to discontinue corticosteroids within two months after splenectomy. Three were men. Their average age was 42 years and the haemoglobin level at presentation ranged from 4.0-9.8 (mean 7.9) $\mathrm{g} / \mathrm{dl}$. In five of the six the sensitisation of the red cell was characterised: in four it was IgG alone, in the other IgG and complement. Six patients needed corticosteroids after splenectomy. All were women. Their average age was 52 and presenting haemoglobin levels ranged from $4-11$ (mean $7 \cdot 7$ ) $\mathrm{g} / \mathrm{dl}$. In only three of these patients was the sensitisation of the red cells characterised and in all it was due to complement alone. The correlation between the spleen uptake of radioactivity and the results of splenectomy was poor (see figure). Theoretically the chances of success after splenectomy should be greatest in quadrants $C$ and $D$ and least in the quadrants $A$ and $B$. But only three of the five patients in quadrants $C$ and $D$ had complete remission after splenectomy. Furthermore, of the five patients lying in quadrant $\mathrm{A}$-the least favourable for splenectomy - three had a complete remission after operation.

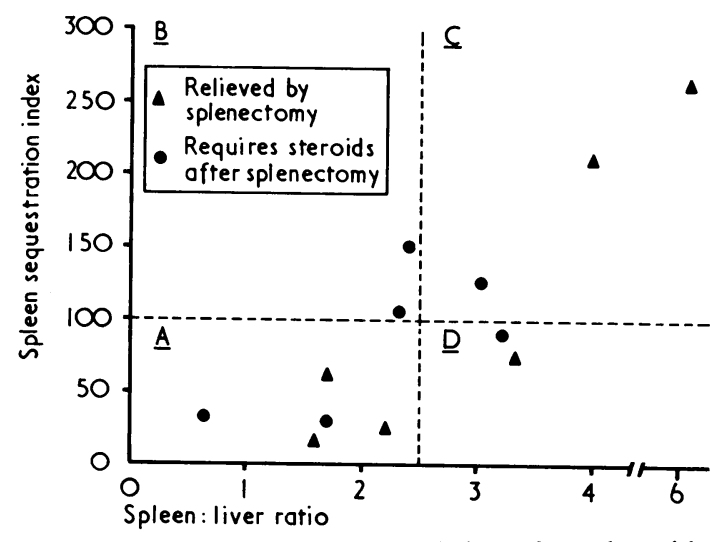

Results of splenectomy and correlation of results with spleen: liver ratio at $t_{2}^{151} \mathrm{Cr}$ and spleen sequestration index. 